\title{
RE-THINKING OF \\ WOMEN PORSTITUTION : PROBLEM OF GENDER PERSPECTIVE
}

\author{
Oleh: \\ Reza Fahmi and Jamaldi \\ Universitas Islam Negeri Imam Bonjol Padang \\ Author Corespondence : rezafahmi@uinib.ac.id
}

Abstract

This research departed from the fact that the Tsunami natural disaster had just passed in Palu, Central Sulawesi. Research objectives: (1) Describe the views of the community about women in the problem of prostitution. (2) Describe gender bias about the stigmatization of women towards the emergence of prostitution that carries a tsunami. (3) Describe the influence of stigmatization of women on their psychological pressure as the cause of the Tsunami. This study uses a quantitative approach. The populations in this study were 287 people using social media (Facebook). The sample in this study was 167 people. The data collected by a psychological scale and documentation study. Analyzed data was used simple regression. The results of this study found the influence of stigmatization of women on the emergence of psychological pressure they received over the Tsunami month ago.

Keywords: Gender Bias, Disaster, Stigmatization and Prostitution.

\section{A. INTRODUCTION}

The natural disasters of the earthquake and tsunami that took place some time ago in Palu and Donggala, Central Sulawesi and various surrounding areas. Leaving sorrow, loss and destruction. Not only physical damage that occurs in the midst of society. But also deep inner suffering, from the loss of family members or relatives. So that natural disasters are a tough test for the people of Palu and Dongggala mainly as affected areas, but also the entire Indonesian people in general. Where the death toll as feared continues to grow, now there are 2,010 people, and in the last search found 46 bodies; while a village isolated in Donggala received assistance for the first time, by helicopter.

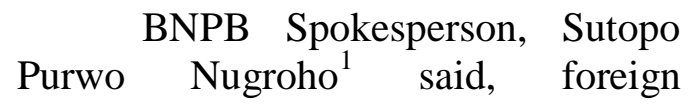

${ }^{1}$ Sutopo also said, on Monday the Basarnas SAR Team found 46 more bodies. So the total number of victims found by the SAR Team was 864 people. While the findings of victims from volunteers and the community were 1,232 people. According to Sutopo, 'unregistered' foreign volunteers or institutions will be 
institutions wishing to contribute to humanitarian assistance, if not through Indonesian partners, would be evicted, as happened in a number of newly returned French volunteers. So far, the most fatalities were found in Palu which reached 1,601 people. While in Donggala 171 people and Sigi 222 people. While the missing victims have reached 671 people $^{2}$.

Regarding the evacuation process, Sutopo said, a coordination meeting had been held which involved BNPB, Basarnas, Regent of Sigi, Mayor of Palu, sub-district head, village head, community leaders, religious leaders, and Kagasgabpad, concluded that the search process would actually be stopped on October 11 . While the location of the former

refused entry to the earthquake and tsunami disaster sites in Central Sulawesi and the government only receives four types of assistance: generator sets, tents, water treatment, and air transportation. "The one who can determine whether or not it needs to be is the Indonesian government. Unless the aircraft needs mechanics, it may be. Water treatment, yes. But if suddenly foreign volunteers keep on doing SAR (search and rescue), yes," said the spokesman BNPB, Sutopo Purwo Nugroho at a press conference at Graha BNPPB, Tuesday (9/10/2018). Previously, five foreign volunteers from ACTED institutions or non-profit organizations from France serving disaster relief were required to leave Palu, under the pretext that the volunteers were not registered in Indonesia. But Sutopo said, even though the foreign institutions were already registered with the Ministry of Foreign Affairs, still they could only be involved in handling disasters in Central Sulawesi if they were related to the four main areas determined by the government. Sutopo stressed that the needs of volunteers in the field have been fulfilled by local volunteers. A number of volunteers and figures from international institutions affected by this policy expressed disappointment at BBC News Indonesia, but refused to give a statement.

${ }^{2}$ https://www.bbc.com liquefaction, will be made a Green Open Space or Memory Park. He also ensured that the location could no longer be used for settlements because it was too dangerous.

Meanwhile, Walandano Village, Donggala District, was visited by the emergency team for the first time, which by helicopter sent one ton of food and drinks to around 1,000 people. Earthquake and tsunami ${ }^{3}$ on the coast of Donggala, the access road was cut off. Walandano village is the closest place to the epicenter of the 7.4 Richter scale earthquake on Friday (9/28). The distance from the city of Palu to the village of Walandano is 115 kilometers. From the air, the helicopter pilot owned by the Air Force, Flight Captain Rizki Randiguna explained that the damaged road was mostly found on the coast of Donggala, the only land access to the village. It is on the peninsula, and far from the city. "Avalanches are visible from the air, a lot, so help must be sent by air." said Captain Rizki to Silvano Hajid and Dwiki Marta from BBC News Indonesia.

After more than a week of emergency conditions, Walandano villagers took refuge independently in a hilly area on the beach. "Villagers are

\footnotetext{
${ }^{3}$ When the earthquake and tsunami struck the city of Palu and its surroundings, on September 28, 2018, several regions such as the Kelurahan Petobo experienced a natural phenomenon called liquefaction. The process that occurred because of this earthquake caused various houses to collapse, cuit Sutopo Purwo Nugroho, Head of the Information and Public Relations Data Center at the National Disaster Management Agency (BNPB). "The surface of the ground moves and sinks so that all buildings are destroyed. The geological process is very terrible. It is estimated that the victims are trapped in this area," said Sutopo.
} 
more cooperative, they don't surround helicopters." Rizki said. From the air, the hilly area suffered minimal damage. In one day, there are two to three trips to isolated places. To the south of Palu, the focus is on sending aid in Sigi Regency, while the western part is focused on Donggala Regency. The BBC News Indonesia team, following the delivery of airborne assistance from Mutiara Sis Aljufri Airport.

The journey by helicopter takes 30 minutes. The worst damage was seen along the coast of Donggala, especially on the promontory where residents of Walandano Village lived. The team only had two minutes to be able to see directly the villagers who immediately came to the aid after being dropped from the helicopter. The picture below shows a Petobo area ${ }^{4}$ the

\footnotetext{
${ }^{4}$ The condition of the Petobo region, South Palu, Central Sulawesi (Central Sulawesi), entered the worst zone affected by the 7.4 magnitude earthquake. A $2 \mathrm{~km}$ stretch of mud land rolled up the area as if it were 'swallowing' houses and cars. "The mud land rolls in Petobo are 2 kilometers long. This is just my length, the width is more than $2 \mathrm{~km}$," said Basarnas member Chandra in Petobo, Central Sulawesi, Tuesday (10/02/2018). Www.detik.com Accessed October 1, 2018. In Petobo, there is a housing complex inhabited by hundreds of residents. After the earthquake and the land around it moved and rolled, the houses seemed to merge with the ground, even like drowning in it. The lands that soaked the house have now begun to harden, although in some parts it still looks wet. The wreck of a four-wheeled vehicle seems to have fused with the ground.

"Sir, I don't want to remember that incident. My trauma," said one of the residents who sat on a pile of Petobo land. Also read: Lament for Petobo, a Village that is 'Swallowed by the Earth' Because of the Earthquake. On the other side of the mound, several members of the Basarnas team were evacuating the earthquake victims. The victim was a mother with her two
}

area of gambling and prostitution in Palu, Central Sulawesi:

Petobo sebelum dan sesudah Tsunami
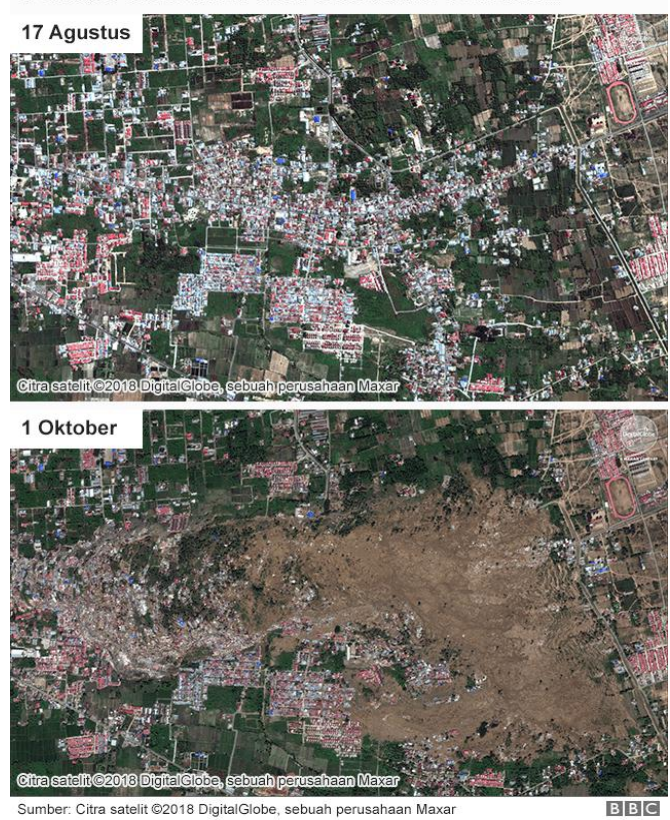

dead daughters. Read also: The Destruction of Palu City Seen from Space This is the Severe Area of Petobo, Houses and Cars 'Swallowed' by the Land Condition in Petobo (Opik / detikcom) The National Police had lowered the K-9 unit to track the whereabouts of the victims. Sadly, these skilled dogs mark dozens of points suspected of being earthquake victims inside. "The K-9 was very helpful to us. They marked the alleged victim and we have given markers on it. The number is up to tens of points," Chandra continued. Until now, of the 2 $\mathrm{km}$ long land rolls in Petobo, only about 500 meters have been opened through the help of a bulldozer. Also See 'Seeing More Obviously the Petobo' Swallowed 'by the Earth During the Earthquake-Tsunami': the earthquake hammer hit the tsunami hammer. 

Figure 1-2 : Before and After the Earthquake and Tsunami Events in Petobo, Palu, Central Sulawesi.

All the facts and data above have illustrated how powerful the earthquake measuring 7.4 on the Rechter Scale and along with the Tsunami hit Palu and its surroundings in Central Sulawesi. Then various scientific analyzes have been explained to the public that, such events are a real form of natural events that might occur in Indonesia. Considering that Indonesia is a ring of fire from an active mountain range. Even so there is a religious analysis which has been run rationally into conversation in the midst of society. Where this was possible because of the existence of prostitution and gambling. With simple language described as a punishment from Allah Subhanahuataa'ala for all immorality committed by mankind. One of the most popular places for illegal sex transactions and gambling is Petobo in Palu, Central Sulawesi.

Petobo Village, South Palu Subdistrict, Palu City is sticking out due to the liquefaction disaster. But who would have thought, when he was still brave. Popular combo with the title of Las Vegas in Palu City. In locations that have claimed 856 casualties, Petobos have been used as nests for gambling, prostitution and narcotics. Yesterday morning, dew seemed to welcome the arrival of Radar Depok who were members of the Bogor and Depok Volunteers. Volunteers visit Petobo affected by liquefaction, or mud that comes out from inside the earth and causes the land of the area to move and be buried. The mud that made mounds and a number of coconut trees became silent witnesses, Petobo was destroyed. Residents there are not ordinary if Petobo is used as an immoral area. One resident of Petobo who survived the liquefaction, Salih said, Petobo used to be like Las Vegas. It is undeniable that Petobo became a gambling place. "The judgments start from nickel class to big class," said Salih when found in one of the houses, which is not far from the entrance to Petobo. Salih revealed, gambling in the Petobo region always lives for 24 hours. In fact, in one day the gambling cycle can reach Rp1 billion. Gambling in these places starts from playing cards, dice, roulette, to other bets. The players, from outside the Petobo region, such as Manado, Makassar, Surabaya to Batam. Whereas for bookies, they are Petobos themselves. All kinds are made gambling in the Petobo region. He did not dismiss, when Depok Radar tried to clarify that pregnant people could be used as gambling, to determine the baby in the male or female womb. In fact, to determine the winner, pregnant women on ultrasound in hospitals are funded by gamblers. "Indeed there is (gambling). In fact, narcotics and prostitution are in Petobo, "explained Salih. The 42-year-old man explained, not half-hearted, indirectly small children become intermediaries. For example, if the parents are togel dealers, their children are often told to deliver money to the winner or the big city. Even for the big city, they live in Petobo 5 .

As if bothering to dig deeper, Radar Depok tried to find the truth where the gambling was actually on the

\footnotetext{
${ }^{5}$ https://radardepok.com/2018
} 
hill. Not far from the Petobo area, there was a copy that was often closed with events wrapped in community activities. So that the outside community does not know that. This time, Salih replied with a smile. According to him, when there is a horse race, the activity is used as gambling. The door is, the Petobo community is given the opportunity to open a business such as a shop stall. A similar statement was also obtained by Radar Depok from other surviving Petobo residents. Nasran said, believing in the liquefaction of the Petobo region was a punishment from God's rebuke, because the region was famous for its immorality. $\mathrm{He}$ confirmed, one of Petobo's gambling sites was on a hill which was often used as a racetrack, motocross and other activities. "It is reported that in addition to the residents of Petobo and migrants from outside the apparatus, they will be behind it," said Nasran. However, all of that is the dark past of Petobo. Now, the Petobo region cannot be resettled. In fact, the plan is for the local government to make petobo a green park and a monument.

Regarding women's prostitution which is a reflection of gender discrimination, where women are victimized as the main source of promiscuity (sex renewal) in the community. This not only happens in social aspects but also in policy aspects. Commissioner of the National Commission on Violence Against Women (Komnas Perempuan) Andy Yentriyani stated that discriminatory policies in the name of religion and morality issued by the regional government continued to grow. Komnas Perempuan notes that there are currently 342 discriminatory policies, increasing from 282 in 2012 and 207 in 2011. 265 of the 342 discriminatory policies that exist, Andi said, directly targeting women in the name of religion and morality.

Of the 265 policies, 76 policies regulate how to dress based on a single interpretation of the religious teachings of the majority population, which according to Andi limits the right to freedom of expression and the right to freedom of religion. In addition, there are 124 policies on prostitution and pornography, 27 policies concerning the separation of male and female public spaces on the grounds of morality - 19 of them use the term khalwat or pervert. There are also 35 policies related to the limitation of night-out hours whose arrangements reduce women's rights to move, work choices and protection and legal certainty, Andi said in his office. National Commission on Violence Against Women reveals areas that have issued many discriminatory policies are West Java, West Sumatra, South Sulawesi, Aceh, South Kalimantan, South Sumatra and East Java. "At present many local governments do not have a human rights and gender perspective," Andi said. Discriminatory policies continue to grow even though in 2012, the State Ministry of Women's Empowerment and Child Protection and the Ministry of Law and Human Rights issued parameters of human rights and gender which became the guideline of the regional government in making a policy. "In our opinion, at the national level, responsible state institutions are hesitant to respond 
(discriminatory regulations), there is no firmness," he said ${ }^{6}$.

The National Commission on Violence Against Women also regretted the proposal for virginity testing which was repeatedly appointed by government officials and members of the regional legislature. Recently, the Prabumulih City Education Service in South Sumatra plans to enter virginity tests in the acceptance of high school and equivalent students in the area in 2014. Previously, this discourse had also been rolled out by the government of Jambi, East Java and Indramayu.

\section{Komnas Perempuan} emphasizes that virginity testing is a form of sexual violence against women and is against the constitution. Such actions lower human dignity and are discriminatory towards women. Virginity tests also have implications for breaking the future of girls because they cannot continue their education and live in a negative stigma within the community, said Chairperson of the National Commission for Law and Policy Reform of the National Commission for Women, Kunthi Tridewiyanti. "Women are not objects but women are subjects that must be respected, they are human beings who have dignity. Therefore the government needs to ensure that education providers, professional institutions and community institutions do not commit sexual violence, because (virginity testing) is sexual violence, "he said. Meanwhile, Deputy Minister of Education and Culture Musliar Kasim said his party would impose sanctions on schools that apply virginity tests to

\footnotetext{
${ }^{6} \mathrm{http} / / / \mathrm{www}$. pikiran-rakyat.com
}

students who want to go to school. "That will make the children worse off. "Because of that, I want to appeal to all local governments that handle the education sector not to take virginity tests to accept new students," he said. "Especially now that for high school we are trying to improve so that more children go to school, our data on children's participation is still low for this secondary school, still 70-80 percent. We are trying to make Indonesian children a minimum of high school parks, if this gap has been made for girls to take virginity tests into school, the effort will be longer, "he added. $^{7}$

The various studies above emphasize how women have been discriminated against by the existing system. Where government policies do not accommodate the interests of women and even women are made as objects of the errors of sexual violence they receive. However, the study we conducted discussed how there had been stigmatization of women in cases of prostitution. Where women are only criminalized as a cause of adultery. While "masher" men get protection in the name of their privilege as leaders. This is where gender bias has become a comprehensive dilemma in Indonesia, which does not only occur in rural areas. But it has also become a belief in the truth by most people.

In other words, women become a source of "disaster" which destroys the order of life of the people. Even though in simple logic economic theory even though we also find peculiarities. Where theoretically the law of supply states "supply increases with increasing

\footnotetext{
${ }^{7}$ http://www.pikiran-rakyat.com
} 
demand". Then if we assume that prostitution is a commodity, if there are no "men" who want sex from prostitutes then there will be no increase in the number of prostitutes in an area. This proves that the increase in the number of prostitutes is always in line with the increasing number of masses who need sexual services from them.

Next this study refers more to the psychological approach as an analytical knife to dissect facts and data in the field, in addition to the use of psychological theory as a guideline for its translation. This is because there are still limited empirical studies on this matter using social media (Facebook) as a method of collecting data. So this is the significance of the study that differentiates this study from previous studies, where this study provides an overview of gender discrimination against women in the issue of prostitution by utilizing the advances in science and technology (use of social media).

\section{B. LITERATURE REVIEW}

\section{- Prostitution}

A little historical record reveals about Indonesian prostitution in the period before the European occupation. It is estimated that long ago there has been a purchase of sex slaves and sexual relations based on pseudo-relationships that commonly occur. During the period of the spread of Islam After the spread of Islam in Indonesia, prostitution was estimated to have increased due to Islamic disapproval of marriage contracts ${ }^{8}$. During the early Dutch colonial period, European men

\footnotetext{
${ }^{8}$ ones, Sulistyaningsih \& Hull 1998, p. 29-30.
}

who wanted to obtain sexual satisfaction began employing prostitutes or concubines from local women. Local women are happy to carry out this act of prostitution in order to be motivated by financial problems, and sometimes even families, who propose their daughters to be prostituted. The rules regarding the prohibition of interracial marriage by the colonial authorities made the practice of prostitution the most acceptable to Dutch leaders.

In the early 1800 s the practice of prostitution began to spread, when the number of concubines was maintained by the Royal Indies army and government officials declined. While the transfer of indigenous men leaving their wives and families to look for work in other areas also contributed greatly to the widespread practice of prostitution at that time. In 1852 the colonial government began to need regular health checks for prostitutes to examine syphilis and other venereal diseases. Prostitutes are also required to carry their job ID cards, although this policy did not succeed in reducing the growth rate of prostitution which increased dramatically during the extensive development period until the end of $1800^{9}$

Prostitution in Indonesia is considered a crime "against morality" and against the law ${ }^{1011}$. In practice, prostitution is widespread, tolerated and regulated. Prostitution is the most visible practice of prostitution, often

\footnotetext{
${ }^{9}$ Jones, Sulistyaningsih \& Hull 1998, p. 30-32

10 "US Department of State: Indonesia". Acsessed 2018-10-21.

${ }^{11}$ Paedophile's Paradise - Indonesia". Journeyman Pictures. Acsessed tanggal 201810-04
} 
manifested in the Indonesian prostitution complex, also known as "lokalisasi", and can be found throughout the country. ${ }^{12}$. This brothel is managed under local government regulations ${ }^{13}$. UNICEF estimates that 30 percent of female prostitutes in Indonesia are women under the age of $18^{14}$. Child sex tourism is also a problem, especially on resort islands such as Bali and Batam ${ }^{15}$.

One of the main reasons for a prostitute to enter business is the attraction of earning money quickly, The Jakarta Post reports that high-class prostitutes in Jakarta can get Rp. 15 million. IDR 30 million (USD 1,755 to $3,510)$ per month. On average, these prostitutes are able to make more than Rp 3 million for each of their service sessions. But the biggest part of the number of those who enter the world of prostitution on the grounds that money comes from the middle class and poor families ${ }^{16}$.

While the other main cause is the pattern of coercion and fraud, where young women from rural and small cities are offered employment opportunities in big cities. But when they arrived in the city these women were raped and forced to prostitute themselves while making money for

12 "Intersections: Traditional and Emergent Sex Work in Urban Indonesia". intersections.anu.edu.au. Acsessed $15^{\text {th }}$ September 2018.

${ }^{13}$ Http://www.catw-ap.org/programs/researchdocumentation-publications/facts-andstatistics/ 14

http://www.humantrafficking.org/countries/ind onesia

15 'INDONESIA: Child sex tourism 'rampant' in S.E Asia". Acsessed 15 ${ }^{\text {th }}$ September 2018.

16 Tampubolon 2010-11-23, Quick money. their pimps ${ }^{17}$. Often parents also offer their daughters to pimps to get money. According to the International Labor Organization (ILO) report that around 70 percent of Indonesian child prostitutes are brought by close family or friends into the world of prostitution $^{18}$. Thus poverty and unemployment are still the main issues accompanying Indonesia which is working towards a process of improvement. At least 37.4 million Indonesians live below the poverty line. This number does not include the Province of Nanggroe Aceh Darussalam and Papua. The obvious and obvious social impacts are those, poor people are excluded from development.

Jaap E Doek, Unicef, and End Child Prostitution Child Pornography reports and The Trafficking of Children for Sexual Purposes (ECPAT) state that trafficking of women and children for sexual exploitation in Asia sacrifices 30 million people, including prostitution. ${ }^{19}$. The prostitution began with forms of sexual harassment and violence such as being poked, groped, and raped. Moreover, female street children often experience sexual violence, such as harassment, rape, persecution, and eventually fall into the world of prostitution. Like prostitution in other provinces in Indonesia, prostitution in South Sulawesi is identical to students under the age of 18 and can be a gateway to the spread of liquor and crime ${ }^{20}$. Besides in big

\footnotetext{
${ }^{17}$ Gunawan 2006-05-23, Teen escapes.

18 The Jakarta Post 2005-07-25, Child prostitutes.

${ }^{19} \mathrm{https}: / / \mathrm{www} . k e m e n p p p a . g o . i d$

${ }^{20} \mathrm{http}: / / \mathrm{www}$.antara-

sulawesiselatan.com/print/5745/profil-antara
} 
cities like in Makassar ${ }^{21}$, prostitution also occurs in tourist attractions such as in Bira Beach, Bulukumba Regency ${ }^{22}$.

Types of Commercial Sex Workers (CSWs) can be divided according to activities and how they work, according to Kartini Kartono in her book Social Pathology, namely: 1. Registered and Organized Types of Commercial Sex Workers (CSWs). The supervisor is monitored by the Police's Vice Control section, who is assisted and works with the Social Service and Health Service. Generally they are localized in one particular area. 2.) Types of Commercial Sex Workers (CSWs) that are not Registered. Commercial sex workers (CSWs) included in this group are those who conduct or prostitute themselves in the dark - dark and wild, both individually and in groups. His actions are not organized, his place is not certain. Can be in any place, either looking for their own prey, or through brokers and callers. They did not register themselves with the authorities. They are forced to carry out their profession, which naturally causes psychological disturbances in the form of being haunted by feelings of guilt and a decrease in self-confidence, which makes them feel uncomfortable in getting along with the community. And those who carry out their profession in an involuntary manner will have the effect of addiction and feel never satisfied with their previous sex partners, so that they will continue to

\footnotetext{
${ }^{21}$ Pelacuran Gadis Bau Kencur di Makassar Terungkap". Diakses tanggal 15 September 2017.

${ }^{22}$ http://kabarmakassar.com/hukumkriminal/item/10685-prostitusi-marak-dibira.html
}

look for partners that match their criteria.

\section{- Social Discrimination}

Discrimination is almost the same as prejudice, sometimes even the two terms are used interchangeably. The difference between the two is that if prejudice is attitude, discrimination is action. Watson ${ }^{23}$ states that discrimination is a negative treatment of certain groups. While Brigham ${ }^{24}$ states that discrimination is treated differently because of its membership in a particular ethnic group. Ethnic groups include ethnicity, language, customs, religion, nationality and others. Swim ${ }^{25}$ states that discrimination is a negative act against people who are objects of prejudice such as racial, ethnic and religious. It can be said that discrimination is prejudice in actions. Thinking that Negroes are stupid is prejudice while forbidding them to work or attend certain institutions because they are black is discrimination. Regarding women as weak people is a prejudice while preventing them from becoming leaders is discrimination.

Discrimination as well as prejudice has a long history and has a tendency to decrease further. In America, restrictions on certain group members to take advantage of public facilities such as schools, public buses, cinemas, gas stations and others are almost nonexistent. Even so, there are still certain types of work that are still oblivious to the element of difference.

\footnotetext{
23 Watson, L. David \& Frank, Joyce.1984. Social Psychology. Scot Foresman company.

${ }^{24}$ Brigham. C. John. 1991. Social Psychology. Harper Collins Publishers Inc.

${ }^{25}$ Baron, A. Robert \& Byrne, Donn. 1991.

Social Psychology. London : Allyn and Bacon.
} 
The position of the Attorney General, the President and other strategic political positions have never been held by black citizens.

The source of this discrimination is almost the same as the source of the emergence of prejudices namely social influences, competition in groups and out groups, historical and other factors. In Indonesia the practice of discrimination still occurs today. A real example is the treatment of the Indonesian government and society towards ethnic Chinese. This discrimination is mainly applied to public education institutions and civil servants and military institutions where in their recruitment regulations always include the conditions of native citizens. So even though it is smart, there are few who go to well-known public universities or schools.

Therefore discrimination refers to services that are unfair to certain individuals, where this service is based on the characteristics represented by the individual. Discrimination is a common occurrence in human society, this is due to the human tendency to discriminate against others. When a person is treated unfairly because of ethnic characteristics, intergroup, sex, race, religion and beliefs, political flow, physical conditions or other characteristics that are suspected to be the basis of acts of discrimination.

Direct discrimination occurs when laws, regulations or policies clearly state certain characteristics, such as gender, race, etc., and inhibit the existence of equal opportunities. Indirect discrimination occurs when neutral regulations become discriminatory when applied in the field. Thus simple social discrimination can be interpreted as differentiating attitudes and treatment of fellow human beings based on their social position.

As with prejudice, discrimination also varies according to the difference in discriminatory objects. The following are some types of discrimination that are generally known in the community:

1. Rasisme (Racism), J. Jones states that racism is a racially differentiating aspect of a culture that is accepted by many people and encourages competition, differences in power and undue treatment of other group members (Brigham. C. John. 1991. Social Psychology. Harper Collins Publishers Inc). This difference in treatment can be manifested individually or through social structures and official institutions. Differences in treatment through institutions are differences in law, the education system, employment, immigration policy, religion and others. Until now there have been several countries that directly or indirectly imposed discrimination based on race. The treatment of the Israeli government against Palestinians is one form of racism that took place in this modern century. Pauline Hanson, leader of the One Nation Party in Australia, is a racist who discriminates against Asians by banning and making it difficult for Asians to settle in Australia. 
Racism in America has two forms, the first is the old fashioned racist, which is a group of people who have a closed view and hold hard on their stand about minorities. This racism developed before the 1900s. After going through various struggles, there is little openness among them, especially towards civil rights issues such as education, economics, politics and social affairs ( John. 1991. Social). The strong resistance to old-style racism has led to what is called modern racism, namely modern racists believe that discrimination is the past and where minorities are too oppressive and get too much sympathy. Here white people have anti-black feelings and commitment to traditional values such as individualism, hard work, ambition and egalitarianism.

Confused attitude towards black people as a result of the conflict between negative feelings towards blacks which he obtained in the early days of socialization and a belief that the American people uphold sportsmanship, fair play, freedom and equality. If old-fashioned racism is applied openly it will hurt and violate egalitarian values. So that, modern racism provides room for indirect or disguised discrimination. The trick is to not allow to be individual, assume no ambition, impulsiveness, depend on the government and others.

2. Tokenism, discrimination often occurs in the economic field, where people are employed or not employed based on race considerations. Tokenism can be simply defined as giving a small amount of positive treatment to a particular group as an excuse to reject a larger positive giving. So minimal positive treatment is used as justification for discrimination in other fields with greater influence. Tokenism is not only done to Negroes in America but also to other minorities such as women, children and the elderly. Kendig, stated that promotion to blacks and women at the age of forty is very rare compared to what happens to white people.

3. Reverse Discrimination, reverse discrimination means a tendency to judge and treat someone from a certain group (usually a target group of prejudices) better than the treatment of other groups. At first the treatment might benefit the target group. So someone does reverse discrimination by giving promotions, salaries and other benefits. For the short term it is profitable but in certain jobs and situations in the long run it will be detrimental. Fajardo, explains this concept by giving an example of the teacher's treatment of his students. A teacher does everything to place students who happen to come from a minority group at a high level.

The existence of this treatment, namely the teacher places students in a risky position because in the end there will be contradictions between improper ranking with the real abilities they have. So that it will ultimately harm the student. This action is based on the reason that the teacher does not want to relate too often to these 
students, thus raising it to a certain level. CSW (commercial sex workers) life is unavoidable from the discrimination treatment they face every day. The discriminatory actions that are often experienced by these commercial sex workers include legislation discriminating against CSWs by prohibiting the practice of prostitution making prostitution a prohibited act without providing appropriate solutions to what sex workers have to do as a more viable source of livelihood. Because it is a job that is not recognized by law, there is no law that provides protection for commercial sex workers. A legal vacuum has become a legal basis for the protection of commercial sex workers as individuals who also have the same rights to be protected by law. Although as a job that is generally prohibited because it is contrary to the moral and cultural values of the community, commercial sex workers are also human persons who have human rights that cannot be discriminated against and have equal position in community life and in law

\begin{tabular}{lcc}
\hline The Categories & $\begin{array}{c}\text { Freq } \\
\text { uency }\end{array}$ & $\begin{array}{c}\text { Percenta } \\
\text { ge }\end{array}$ \\
\hline 1 The Gender & 80 & 47.90 \\
Male & 87 & 52.10 \\
\hline Female & $\mathbf{1 6 7}$ & $\mathbf{1 0 0 . 0 0}$ \\
Sum & & \\
\hline Students & & \\
\hline Work Place & & 46.71 \\
\hline Civil Servent & 78 & \\
\hline
\end{tabular}

and are entitled to protection to ensure their rights.

\section{METHODS}

This study uses a quantitative approach. The populations in this study were 287 people were using social media (Facebook). The sample in this study was 167 people. The data collected by a psychological scale and documentation study. The simple random sampling was choosen as technical sample, because the data based on the people who joint our facebook members. The analyzed data was used simple regression.

\section{RESULT AND DISCUSSION}

There were two kinds of research finding in this research : (1) Descriptive analysis of respondent and spreading of mean data of variables. (2) The quanitiative analysis and testing of the hypotesis.

Table 1.1 : The Descriptive Analysis of Respondent

\begin{tabular}{lcc}
\hline Non Civil Servent & 89 & 53.29 \\
\hline Sum & $\mathbf{1 6 7}$ & $\mathbf{1 0 0 . 0 0}$ \\
\hline $\begin{array}{l}\text { Education } \\
\text { Background }\end{array}$ & 12 & 7.19 \\
\hline $\begin{array}{l}\text { Third Degree (Ph.D) } \\
\text { Second Degree } \\
\text { (Masters) }\end{array}$ & 67 & 40.12 \\
\hline $\begin{array}{l}\text { First Degree } \\
\text { (Bachelor) }\end{array}$ & 88 & 52.69 \\
\hline Sum & $\mathbf{1 6 7}$ & $\mathbf{1 0 0 . 0 0}$ \\
\hline
\end{tabular}




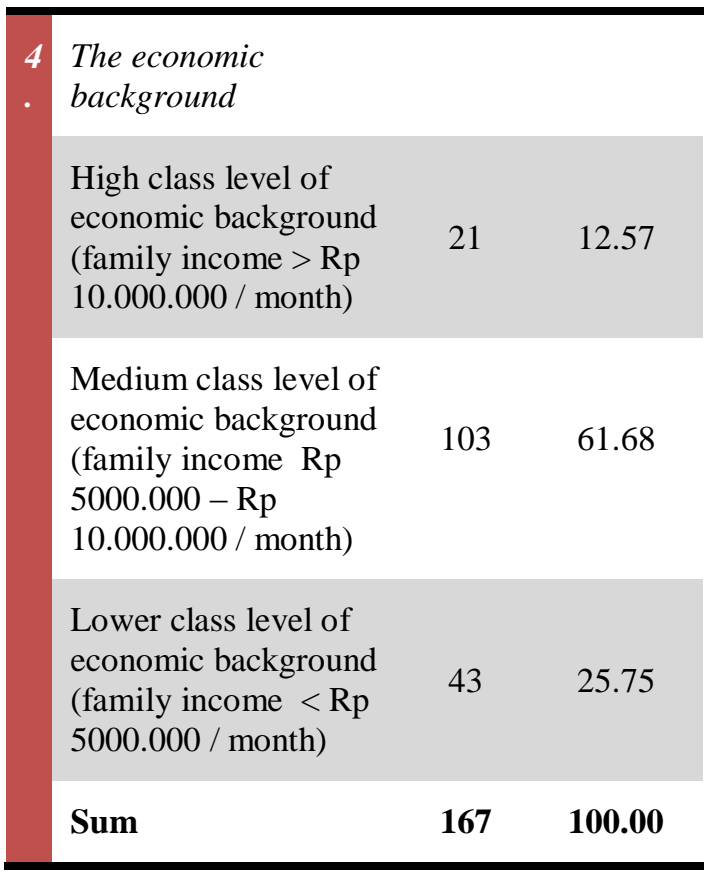

Sources: The reserach reports 2018

According to Table 1.1 we found that the amount percentages of female $87(52.10 \%)$. more than male 80 (49.10\%). Then, the respondents that worked as non-civil servent ( 89 or $53.29 \%$ ) more than the respondents worked as civil servent 78 (46.71\%). Most of the respondents had a first degree background of education level 88 (52.69\%). Some of them were Masters degree background of education level 67 (40.12\%). Only a few of respondents had Ph.D degree background of education level (12 or $7.19 \%)$. According to the economic background, most of the respondents came from middle class income 103 $(61.68 \%)$. The amount of respondents who came from lower class income 43 $(25.75 \%)$. Then, the respondents who had high level income 21 (12.57\%).

Table 2.1 The mean spreading, frequency and percentage of perception of women's as resources prostitute

\begin{tabular}{|ccc|}
\hline The Categories & Frequency & $\begin{array}{c}\text { Percentage } \\
\text { s }\end{array}$ \\
\hline High & 123 & 73.65 \\
\hline Low & 44 & 26.35 \\
\hline Sum & $\mathbf{1 6 7}$ & $\mathbf{1 0 0 . 0 0}$ \\
\hline
\end{tabular}

Sources: The research reports, 2018

According to the Table 2.1 above, most of mean spreading on perception about women's prostitute categorized high (123, equal with $73.65 \%)$. Then, some of them categorised low (44, equal with $26.35 \%$ ). the community generally gives a negative stigma to the existence of this profession (prostitutes ${ }^{26}$ ). For example, this profession is considered as community waste, a household destroyer, and is perceived as a occupant of the black area. Localization developed along with the rapid population growth, especially from urbanization and population movements from other regions and

\footnotetext{
${ }^{26}$ Prostitutes are professions that sell services to satisfy a customer's sexual needs. Usually this service is in the form of renting out his body. Among Indonesians, prostitution is seen as negative, and those who rent or sell their bodies are often regarded as community waste. There are also those who consider prostitution to be bad, even evil, but it is needed (evil necessity). This view is based on the assumption that the presence of prostitution can channel the sexual desires of those who need it (usually men); without this distribution, it is feared that its customers will attack and rape women well. The term prostitute is often refined with commercial sex workers, prostitutes, other terms that also refer to commercial sex services. Especially for men, the term gigolo is used.
} 
cities.

Commercial sex workers or prostitutes are women who have a habit of having sex outside of marriage, whether in return for services or not. Prostitution or prostitution is essentially a sexual behavior that changes partners, can be done by men and women. In Indonesia, the practice of prostitution is mostly carried out by women, although it is undeniable that the practice of prostitution by men has begun to be numerous and there are also practices of prostitution along inter-city crossing routes.

The main reason for a person's plunge in the practice of prostitution is an economic problem; because of limited education and demoralizing behavior they see prostitution as one of the jobs as well as a very promising profession to earn a lot of money. The factor that most determines one's involvement in the practice of prostitution is economic pressure. In an era of rapid development towards an industrialized country, competition for good livelihood is largely determined by one's education level. The competitiveness of someone with higher education is certainly stronger than those with low education, in addition to the increasingly limited field of work.

The monetary and economic crisis has had a systemic impact on people's lives, especially in economic aspects. This certainly results in an increasing number of unemployed people and eventually becomes a driving factor for workers to do anything to get money even if it is against the law, morals, and ethics such as stealing, and working as commercial sex workers. The impact of the phenomenon of female sex workers is certainly no stranger. In every corner of the city often found women commercial sex workers in action looking for masher men. Even this phenomenon also touches educational institutions such as secondary schools and universities. This is considered very taboo in the community, considering that our country is a country with eastern customs and has very strong norms in society. So, the prostitutes got ridicule and insults from the community. This then greatly affected the psychological condition of prostitutes.

It has become our knowledge together, there are many people who isolate CSWs, and that also applies to the families of CSWs. The community also mocked and looked down on the family of the prostitute, for example the child of a prostitute, the child of a prostitute would be ostracized by their peers, because the parents of the children were worried that their children would be affected because they assumed that their mother worked like so the child will be too.

Table 3.1 The mean spreading, frequency and percentage of gender bias on women's prostitute

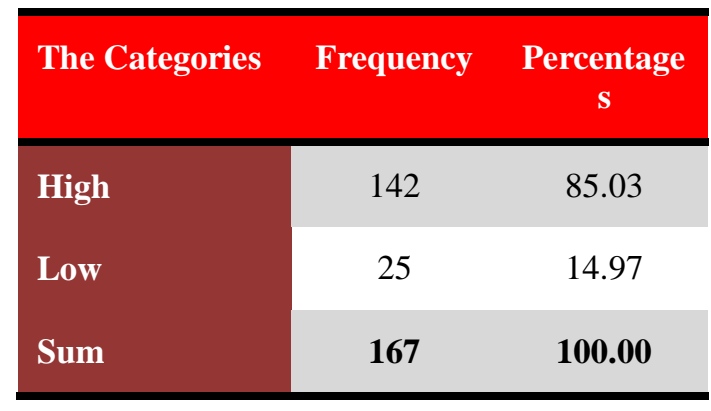

Sources : The research reports, 2018 
According to the Table 3.1 above, most of mean spreading of frequency and percentage of bias gender on women's prostitute categorized high (142, equivalent with 85.03). But only $25(14.97 \%)$ had gender bias categoriesed low (15.97). It means among respondents, CSWs (commercial sex workers) are seen as negative, and those who rent or sell their bodies are often regarded as community waste. CSWs have been so despicable and become enemies of the people, they are often deforested if they are caught by law enforcement officers, they were also evicted for being considered harassing religious purity and they were also brought to court for violating the law. If people know someone in their environment is a prostitute, in general they will isolate him and give him unfair treatment. The community does not only look down on existing CSWs but they also look down on the CSW family (father/ mother) because they are considered unable to provide good education for their children.

According to Socrates ${ }^{27}$, every person certainly has something he believes in as his God, even an atheist must adhere to a belief which he considers to be the most wise and good power. For women who are prostitutes because of forced factors, sooner or later they will feel guilty and sinful towards their Lord, because in essence they know that what they do is a despicable act and cannot be accepted in any religious group. But, even though they are aware, they remain cannot stop his work for his survival. On the one hand the guilt continues to

\footnotetext{
${ }^{27}$ Kartini Kartono. 2001. Psikologi Sosial. Jakarta: Rajawali.
}

haunt, while on the other hand they have to think about their survival. It is very difficult to balance two pressures whose strength is opposite. The longer the pressure occurs, and then the mind of the sex workers will get worse and eventually can cause their souls disturbed and even experience mental disorders. In addition, it cannot be denied that sex is a psychic energy that contributes to human behavior, for example sex relations or intercourse. According to Koentjoro ${ }^{28}$, women commercial sex workers always experience conflicts within themselves, both conflicts of interest between feeling in need of money and feelings of sin, or also because of feelings of insecurity about their status as commercial sex workers in the community. Normal sexual intercourse implies: the relationship does not cause adverse effects, does not cause psychological conflicts and no coercion. Thus sex should be carried out in a regular bond, namely marriage. Beyond that provision, sexual relations can be classified in sexual mental disorders, namely abnormal sexual relations and perverse.

Table 4.1 The Correlation Analysis

\footnotetext{
${ }^{28}$ Kartini Kartono. 2001. Psikologi Sosial. Jakarta: Rajawali.
} 


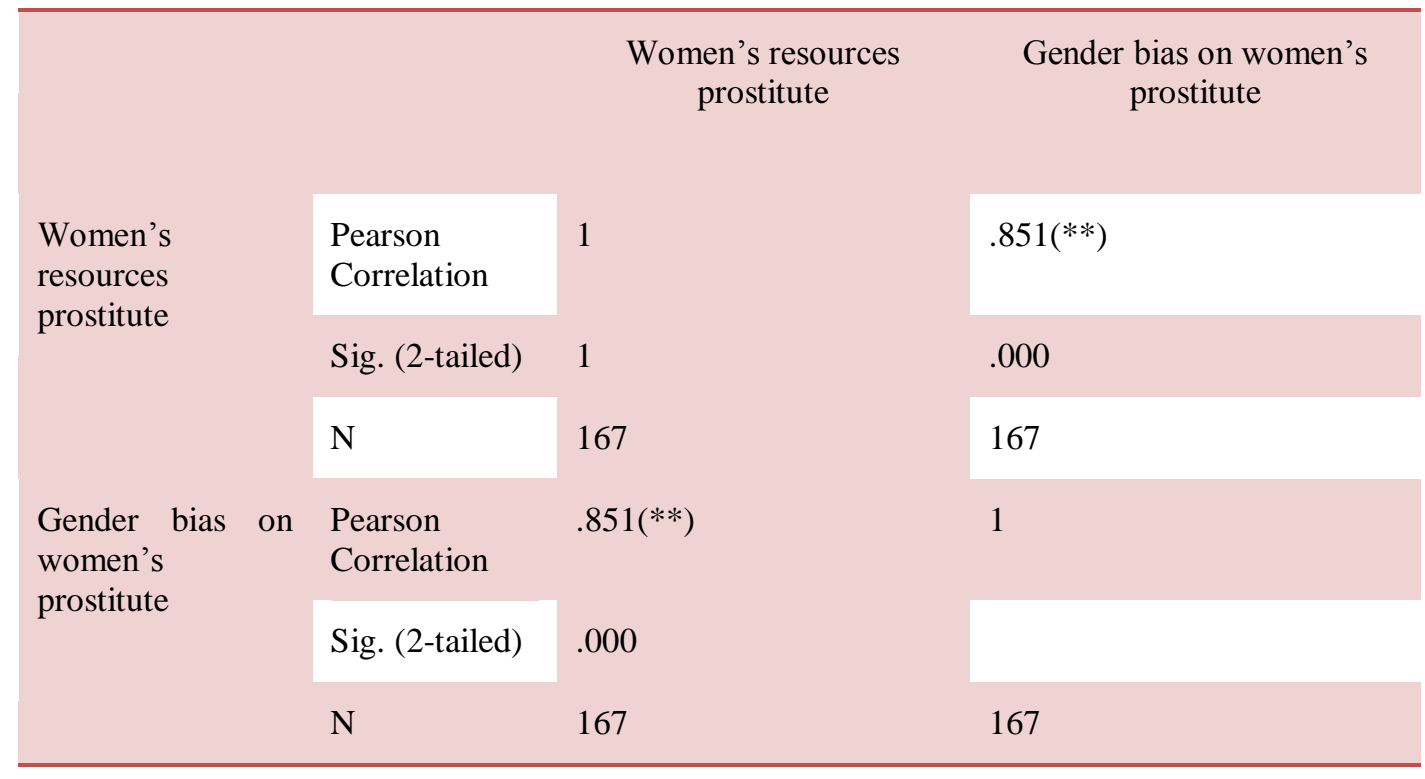

** Correlation is significant at the 0.01 level (2-tailed).

According to The table 4.1 above, we lacking. So that the assumption of got information that $\mathrm{r}_{\text {score }}=0.851$. stigmatization of women is Then the table score $=0,096$ and $\mathrm{p}=$ increasingly strong as a source of $0.000<0.05$. It means $\mathrm{H}_{\mathrm{o}}$ was rejected prostitution. Furthermore, they do not and recieved $\mathrm{H}_{1}$. So, there were any have sufficient access to develop correlation between perception of personal skills, making it the easiest women's as resources prostitute and gender bias on women's prostitute. Its means that the more negative social stigma (resources of prostitute were a women) on women's prostitute, then the more gender bias on women's prostitute. A low bargaining position in the competitive labor market makes women or women forced or forced to work as prostitutes. So they tend to be made "scapegoats" in the matter of prostitution.

Besides that they have no other choice to work, because education is choice to become commercial sex workers to earn money. Furthermore, they also did not get social support from the community to be able to escape from the prostitution area. Plus the lack of attention from the government to deal with the problem more seriously, because there are individuals or groups of people who take advantage of the prostitution business.

Tabel: 5.1 Model Summaries

\begin{tabular}{|c|c|c|c|c|}
\hline $\begin{array}{l}\text { Mode } \\
1\end{array}$ & $\mathrm{R}$ & R Square & Adjusted R Square & $\begin{array}{l}\text { Std. Error of the } \\
\text { Estimate }\end{array}$ \\
\hline 1 & $.317(\mathrm{a})$ & .700 & .091 & 8,041 \\
\hline
\end{tabular}




\begin{tabular}{|l|rrrrrr|}
\hline $\begin{array}{l}\text { Mod } \\
\text { el }\end{array}$ & & Sum of Squares & Df & Mean Square & F & Sig. \\
\hline 1 & Regression & 1425,928 & 3 & 712,964 & 11.026 & $\begin{array}{r}.00 \\
0(a)\end{array}$ \\
\hline & Residual & 12803,545 & 137 & 64,664 & & \\
\hline & Total & 14229,473 & 139 & & \\
\hline & According to & Table & 5.1 we & inability of husbands to play a role as \\
\hline
\end{tabular}

cause the a role as found that the $\mathrm{R}$ square $=0.700$ (it's breadwinners cause the family's coming from $0,35 \times 0,35=0.700$ ). $\mathrm{R}$ economic condition to be weak so they square is a determinant of coefficient. replace the role as breadwinners for That means: only $70 \%$ the effect of their families. Husbands who get sick perception (stigmatization) of. Then, for too long so that they are no longer $30 \%$ were depending on any other productive to work, so they replace factors. I.e. poverty, jobless, lack of their husband's role, and there is also education, economic depression etc.

\section{E. CONCLUSION}

Giving a negative stigma to women as a source of prostitution problems does not solve the problem. Even making women worse off and difficult to get out of the circle of prostitution. Then the community needs to be wise in assessing that female prostitution is an empirical reality that needs to be solved together. So do not just make women as objects of sufferers from the problem of prostitution, which leads to the emergence of natural disasters. But make them as subjects that need to be included in development by making them active participants in the development itself by developing their potential.

The decision to become a female commercial sex worker is influenced by several factors. Factors that influence not only external factors that come from outside, but also internal factors that originate from within him. Economic factors and the because the income of husbands who are unable to meet their family needs encourages them to decide to become female commercial sex workers. The opening up of opportunities to become female commercial sex workers is also one of the factors that influence the decision to become female commercial sex workers. The invitation of friends who had previously become women commercial sex workers in massage parlors for example, eventually became female commercial sex workers.

Pessimism towards employment is an important factor affecting a woman to become a commercial sex worker. They feel pessimistic about getting a decent job with their educational background. Some decisions to choose to become female commercial sex workers indicate a lack of understanding of religious values so that subjects prefer to become job women as an easy and fast way to earn income. Conflict did not just end when the subject decided to become a female commercial sex worker because many conflicts actually arose in her. They are faced with 
intrapersonal conflict and interpersonal conflict. The many necessities of life that must be fulfilled caused them to be unable to carry out their wishes to stop immediately because the subject became the backbone of their family.

Awareness of the role that must be carried out in the family also leads to role conflict in CSWs. The wife must be loyal to her husband, be at home and take care of the child, obliged to serve her husband, and not work so that at any time her children

\section{REFERENCES}

Baron, A. Robert \& Byrne, Donn.1991. Social Psychology. London : Allyn and Bacon.

Brigham. C. John. 1991. Social Psychology. Harper Collins Publishers Inc.

Gerungan. W.A. 1996. Psikologi Sosial. Bandung : Penerbit PT. Eresco

Hadi, Sutrisno. 2000. Isu Uji Asumsi. Makalah. Jogjakarta : Universitas Gadjah Mada (tidak diterbitkan)

Hadi, Sutrisno.2000. Statistik II. Jogjakarta. Penerbit ANDI

Joko Kuncoro. 2017. Prasangka dan Diskriminasi. Resipatori. Semarang: UNISSULA. need her mother, ideally her mother is always beside her children. Awareness of their obligations as a mother and wife causes guilt to arise because they always leave their children to work. As a wife, she should be able to take care of her husband, clean the house, serve her husband and be loyal to her husband, but with her work as a commercial sex worker who must serve many guests who are not her husband causes them to feel guilty of betraying their husband.

Kartini Kartono. 2010. Psikologi Abnormal. Jakarta: Rajawali Press.

Kartini Kartono. 2012. Patologi Sosial. Jakarta: Rajawali Press.

Kartini Kartono. 2011. Kenakalan Remaja. Jakarta: Rajawali Press.

Myers, G. David.1983. Social Psychology. Mc Graw-Hill Company.

Soekanto, Soerjono. 1999. Sosiologi Suatu Pengantar. Jakarta : PT. RajaGrafindo Persada. RajaGrafindo Persada.

The Jakarta Post 2005-07-25, Child prostitutes 